\title{
Monocyanomethylated thiacalix[4]arenes: synthesis and lower rim modification
}

\author{
Vladimir Kovalev,* Elena Khomich, Elvira Shokova, and Yurij Luzikov \\ Laboratory of Macrocyclic Receptors, Chemistry Department of Moscow State University, \\ Moscow 119991, Russia \\ E-mail: kovalev@petrol.chem.msu.ru
}

Dedicated to Prof. I. Beletskaya on the occasion of her $75^{\text {th }}$ birthday

\begin{abstract}
The selective monocyanomethylation of $p$-R-thiacalix[4]arenes $(\mathrm{R}=\mathrm{H}$, tert-Bu) with chloroacetonitrile in the presence of $\mathrm{Na}_{2} \mathrm{CO}_{3}$ in DMF is described. Monocyanomethylated p-tertbutylthiacalix[4]arene has been synthetically exploited in the Ritter reaction with 1-adamantanol for the transformation to the corresponding amide. A thiacalix[4]arene having mixed amide and ester functionalities at the lower rim was synthesized by alkylation of 25-N-(1adamantyl)carbamoylmethoxy-p-tert-butylthiacalix[4]arene with ethyl bromoacetate.
\end{abstract}

Keywords: Thiacalix[4]arenes, $O$-monocyanomethylation, Ritter reaction, adamantylamides

\section{Introduction}

Tetrathiacalix[4] arenes ${ }^{1}$ are novel widely developed members of the calixarene family in which the methylene bridges are replaced by sulfur atoms. The introduction of a heteroatom as a bridge provides an additional opportunity to tune the ring size, conformational and binding properties of a macrocycle. Since the starting $p$-R-thiacalix[4]arenes $(1, \mathrm{R}=$ tert-butyl, tert-octyl, 1-adamantyl or phenyl $)^{2-5}$ are accessible now in multi-gram scale, these macrocycles have sparked a great deal of interest as building blocks in the synthesis of more complicated systems.

The regioselective alkylation and acylation of the lower rim hydroxyls of the classical calix[4]arenes have become important synthetic tools for the construction of a great variety of synthetic receptors. Unfortunately, similar regioselective reactions cannot be performed on the thiacalix[4]arene platform to the same extent of efficacy. The lower apparent differences in the $\mathrm{OH}$ acidities $^{6}$ of the thiacalix[4]arenes as compared to the classical ones prevents the regio- and stereoselective partial $O$-alkylation and acylation of thiacalix[4]arenes . As a result, the relatively 
easy formation of tetralkylated thiacalix[4]arenes ${ }^{7}$ or thiacalix[4](bis)crown ethers ${ }^{8}$ takes place simply in the presence of alkali metal carbonates.

With respect to partial $O$-alkylation of thiacalix[4]arenes, only a few 25,27-dialkoxythiacalix[4]arenes ${ }^{9}$, distally bridged thiacalix[4](mono)crown ethers ${ }^{8 b, c}$ and several partially acylated derivatives ${ }^{10}$ have been prepared although in only moderate yields. Recently expedient routes to 1,3- and 1,2-diethers via the Mitsunobu reaction, ${ }^{11}$ or via proximal O,O'-disiloxane bridge intermediates ${ }^{12}$ have been proposed to overcome the problems encountered in basemediated alkylations. In this paper we report the first examples of the selective monoalkylation of thiacalix[4]arene and some chemical transformation of the monocyanomethylated thiacalix[4]arenes.

\section{Results and Discussion}

The products formed from the base-mediated alkylation of calixarenes are very sensitive to the choice of the reaction conditions. With this consideration in mind the reactions between $p-\mathrm{R}-$ thiacalix[4]arenes $\mathbf{1 a}$ and $\mathbf{1 b}(\mathrm{R}=$ tert-Bu, $\mathrm{H}$, respectively) and chloroacetonitrile was studied using the following different reaction conditions: (i) Method "A" $=\mathrm{ClCH}_{2} \mathrm{CN} / \mathrm{M}_{2} \mathrm{CO}_{3}(\mathrm{M}=\mathrm{Na}$, $\mathrm{K}$ ) $/ \mathrm{NaI}$ in refluxing acetone; (ii) method "B" $=\mathrm{ClCH}_{2} \mathrm{CN} / \mathrm{Cs}_{2} \mathrm{CO}_{3}$ in refluxing acetonitrile; and (iii) "C" $=\mathrm{ClCH}_{2} \mathrm{CN} / \mathrm{M}_{2} \mathrm{CO}_{3}(\mathrm{M}=\mathrm{Na}, \mathrm{K}) / \mathrm{NaI}$ in $\mathrm{DMF}$ at $60^{\circ} \mathrm{C}$. When applied to the classical calix[4]arenes ${ }^{13}$ method $\mathbf{A}$ produces distal dicyanomethoxy derivatives; procedure $\mathbf{B}$ has been proposed recently ${ }^{14}$ for the synthesis of tetracyanomethoxy-p-H-calix[4]arene as a mixture of cone and paco conformers. In the case of thiacalix[4]arenes, it is known ${ }^{15}$ that the alkylation of p-tert-butylthiacalix[4]arene 1a with chloroacetonitrile conducted under the same conditions as used for the conventional calix[4]arene $\left(1 \mathbf{a} / \mathrm{ClCH}_{2} \mathrm{CN} / \mathrm{K}_{2} \mathrm{CO}_{3} / \mathrm{NaI}=1: 4: 4: 4\right)$ in acetone did not give the desired 1,3-dialkylated product but instead, formed a complex intractable mixture, and only the use of expensive $\mathrm{Cs}_{2} \mathrm{CO}_{3}\left(\mathbf{1 a} / \mathrm{ClCH}_{2} \mathrm{CN} / \mathrm{Cs}_{2} \mathrm{CO}_{3} / \mathrm{NaI}=1: 3.5: 1: 3.5\right)$ in refluxing THF gave the 1,3- and 1,2-dialkylated products in 70 and $<1 \%$ yields, respectively.

We found that reaction of $p$-(tert-butyl)thiacalix[4]arene 1a using the modified reaction conditions $\mathbf{A}\left(\mathbf{1 a} / \mathrm{ClCH}_{2} \mathrm{CN} / \mathrm{K}_{2} \mathrm{CO}_{3}\right.$ or $\left.\mathrm{Na}_{2} \mathrm{CO}_{3} / \mathrm{NaI}=1: 8: 8: 8\right)$ in refluxing acetone for up to $38 \mathrm{~h}$ afforded only a small amount of a mixture of cyanomethylated products, and mainly unreacted starting material ( $\sim 90 \%)$. A similar reaction with $\mathbf{1 b}\left(\mathrm{Na}_{2} \mathrm{CO}_{3}\right.$ as a base) proceeded faster with full conversion of parent thiacalix[4]arene, but led to a complex mixture of mono- and polyalkylated products. In this case, column chromatography afforded monocyanomethoxy-p-Hthiacalix[4]arene $\mathbf{2 b}(\sim 30 \%)$ and a mixture of regio- and conformational isomers of polycyanomethylated $p$-H-thiacalix[4]arenes $(\sim 40 \%)$. Under reaction conditions $\mathbf{B}$ (10 equiv. $\mathrm{ClCH}_{2} \mathrm{CN}$ and 10 equiv. $\left.\mathrm{Cs}_{2} \mathrm{CO}_{3}, 25 \mathrm{~h}\right) \mathbf{1 b}$ also underwent complete conversion into a mixture of cyanomethylated products, with lack of selectivity.

Unexpected results were obtained when procedure $\mathbf{C}$ was applied. It turned out that heating 1a in DMF at $60{ }^{\circ} \mathrm{C}$ for $25 \mathrm{~h}$ in the presence of 10 equiv. $\mathrm{ClCH}_{2} \mathrm{CN}, 10$ equiv. $\mathrm{Na}_{2} \mathrm{CO}_{3}$ and 1 
equiv. NaI formed the monocyanomethylated compound $(\sim 13 \%)$ only, and the $78 \%$ of starting material was recovered. The same result was obtained in the presence of $\mathrm{K}_{2} \mathrm{CO}_{3}$ as a base. By increasing of the molar ratio $1 / \mathrm{ClCH}_{2} \mathrm{CN} / \mathrm{Na}_{2} \mathrm{CO}_{3} / \mathrm{NaI}$ up to 1:50:50:2 the yield of 25cyanomethoxy-p-(tert-butyl)calix[4] arene 2a was raised to 36\%. Under these conditions polynitriles were not formed and only starting compound (53\%) was recovered from the reaction. Using the same conditions, $\mathbf{1 b}$ gave the desired mononitrile $\mathbf{2 b}$ in high yield ( $51 \%)$ accompanied with a small amount of polynitriles $(\sim 13 \%)$.

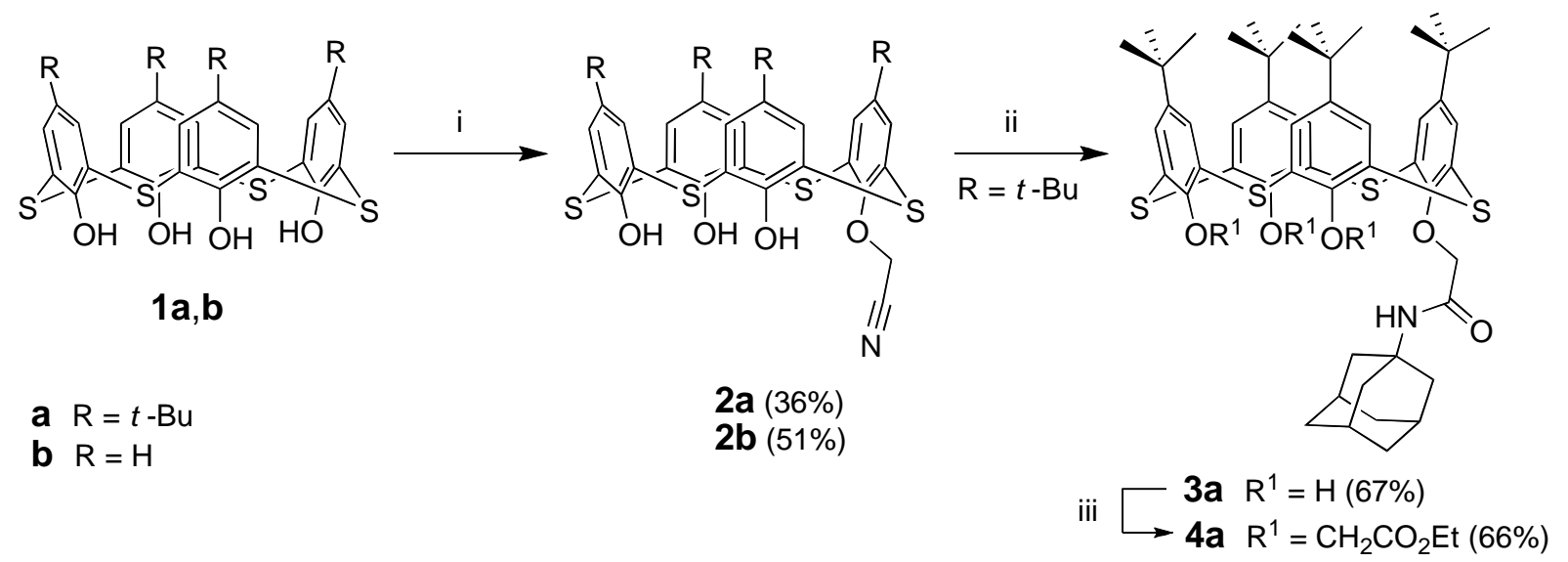

Scheme 1. (i) $\mathrm{ClCH}_{2} \mathrm{CN}, \mathrm{Na}_{2} \mathrm{CO}_{3}, \mathrm{NaI}, \mathrm{DMF}, 6{ }^{\circ} \mathrm{C}$; (ii) 1-adamantanol, $\mathrm{CF}_{3} \mathrm{CO}_{2} \mathrm{H}, \mathrm{C}_{2} \mathrm{H}_{4} \mathrm{Cl}_{2}, 80$ ${ }^{\circ} \mathrm{C}$; (iii) $\mathrm{BrCH}_{2} \mathrm{COOEt}, \mathrm{Na}_{2} \mathrm{CO}_{3}$, acetone, reflux.

The structures of compounds prepared were proved by NMR measurements. The ${ }^{1} \mathrm{H}$ NMR spectrum of 2a unambiguously reflected the ABBB ring symmetry of the monoalkylated thiacalix[4]arenes. The three singlets $(1.28,1.26$ and $1.17 \mathrm{ppm}$ in 2:1:1 ratio) for the tert-butyl groups, the one singlet $(5.50 \mathrm{ppm})$ for the $\mathrm{OCH}_{2} \mathrm{CN}$ group and splitting of the aromatic signals into two doublets ( 7.69 and $7.65 \mathrm{ppm}$ with the typical meta coupling $J=2.4 \mathrm{~Hz}$ ) and two singlets (7.66 and $7.59 \mathrm{ppm}$ ) were all indicative for the monosubstituted structure of $2 \mathbf{a}$.

In contrast to thiacalix[4]arenes, p-(tert-butyl)calix[4]arene gave the 25,27-syn-dicyanomethoxy derivative in $62 \%$ yield using procedure C. The results obtained reconfirm the differences observed in the chemical behaviour of classical calix[4]arenes and their thiaanalogues in their respective alkylation reactions. The monocyanomethylation of $p$-(tert-butyl)and $p$-H-calix[4]arenes has been realized recently using an equimolar amounts of bromoacetonitrile and alkaline metal carbonates (1.0 equiv. $)^{16}$ or bis(tributyltin)oxide $(0.5 \text { equiv. })^{17}$ as bases.

The success of the monoalkylation achieved enables the preparation of thiacalixarenes having mixed functionalities at the lower rim. This aim was successfully attained by using the Ritter reaction protocol for the transformation of nitriles to amides. Earlier we showed ${ }^{18}$ that secondary and tertiary alcohols can be used as alkylation agents in the Ritter reaction in trifluoroacetic acid (TFA) for the lower-rim modification of 25,27-dicyanomethoxy- $p$-Rcalix[4]arenes. It has now been found that heating 25-cyanomethoxy-p-(tert-butyl)- 
thiacalix[4] arene 2a with a twofold excess of 1-adamantanol in TFA- $\mathrm{C}_{2} \mathrm{H}_{4} \mathrm{Cl}_{2}$ medium afforded $25-[N$-(1-adamantyl)carbamoylmethoxythiacalix[4]arenes 3 in $67 \%$ yield.

${ }^{1} \mathrm{H}$ NMR spectra of monoamide 3 reflects practically the same splitting patterns for the aromatic and tert-butyl protons as were observed in the spectra of monocyanomethylated derivatives 2a. In addition however, the broad signals of the adamantane protons in the 1.6-2.1 ppm region were clearly observed. The ${ }^{13} \mathrm{C}$ NMR spectra proved to be more informative for the identification of the adamantane fragment in this molecule since in accordance with the monosubstitution feature of the adamantane nucleus, four signals due to the adamantane fragment carbons were observed.

The synthesis of thiacalix[4]arene 4a having mixed amide and ester functionalities at the lower rim was achieved by alkylation of 25-[N-(1-adamantyl)carbamoylmethoxythiacalix[4]arenes 3a with $\alpha$-bromoethyl acetate (60 equiv.) in refluxing anhydrous acetone, in the presence of $\mathrm{Na}_{2} \mathrm{CO}_{3}$ (60 equiv.). The choice of sodium carbonate in preference to potassium carbonate was determined by the fact that sodium-containing compounds have been the usual bases used for the synthesis of cone conformers ${ }^{7, c}$ in thiacalixarene series. Although this reaction required a long refluxing period $(40 \mathrm{~h})$, the triester $4 \mathrm{a}$ was isolated in good yield $(66 \%)$ and with a complete stereoselectivity for the cone conformation, as was proved by ${ }^{1} \mathrm{H}$ and ${ }^{13} \mathrm{C}$ NMR analysis. The ${ }^{1} \mathrm{H}$ NMR spectrum of $\mathbf{4 a}$ contained three signals due to the tert-butyl groups $(1.14,1.10,1.06)$, four signals in the aromatic region consisting of two doublets (7.37 and $7.33 \mathrm{ppm})$ with a typical meta-coupling constant $(J=2.6 \mathrm{~Hz})$ and two singlets $(7.34$ and 7.21 ppm). In the region for the $-\mathrm{OCH}_{2} \mathrm{CO}$ - protons, two singlets for the $-\mathrm{OCH}_{2} \mathrm{CONHAd}$ group and its counterpart, $-\mathrm{OCH}_{2} \mathrm{COOEt}$ group, at 4.87 and $5.06 \mathrm{ppm}$ respectively, were observed. The signals due to the methylene hydrogen atoms of the two remaining ester groups were split into two doublets at 5.29 and $5.09 \mathrm{ppm}$ as a result of the $\mathrm{H}_{\mathrm{A}}-\mathrm{H}_{\mathrm{B}}$ geminal interactions. The signals of the ethoxy group protons were evident as two sets of multiplets at 4.23 and $1.28 \mathrm{ppm}$.

In conclusion, we have demonstrated for the first time the selective mono-Ocyanomethylation of $p$-R-thiacalix[4]arenes $(\mathrm{R}=$ tert-Bu, $\mathrm{H})$ with chloroacetonitrile using $\mathrm{Na}_{2} \mathrm{CO}_{3}$ as the base in the presence of $\mathrm{NaI}$, in $\mathrm{DMF}$, at $60^{\circ} \mathrm{C}$. Nitrile 2a was converted into the corresponding amide $3 \mathbf{a}$ in high yields by the Ritter reaction with adamantanol in trifluoroacetic acid, hence providing a simple access to a thiacalix[4]arene 4a having mixed functionalities at the lower rim.

\section{Experimental Section}

General Procedures. ${ }^{1} \mathrm{H}$ and ${ }^{13} \mathrm{C}$ NMR spectra were measured on a Bruker Avance 400 spectrometer with solvent signals as internal reference. Chemicals were commercial grade and were used without further purification. Preparative column chromatography was carried out on Kieselgel 40/60 (Merck), and TLC analysis was performed on DC Alufolien Kieselgel $60 \mathrm{~F}_{254}$ 
plates (Merck) with UV development. Solvents were purified and dried according to standard procedures.

\section{Synthesis of 25-cyanomethoxy-p-R-thiacalix[4]arenes 2. General procedure}

A mixture of 1 (1 mmol), chloroacetonitrile $(3.2 \mathrm{~mL}, 50 \mathrm{mmol}), \mathrm{Na}_{2} \mathrm{CO}_{3}(5.3 \mathrm{~g}, 50 \mathrm{mmol})$ and $\mathrm{NaI}(0.3 \mathrm{~g}, 2 \mathrm{mmol})$ in anhydrous DMF $(40 \mathrm{~mL})$ was stirred at $60{ }^{\circ} \mathrm{C}$ for $38 \mathrm{~h}$. The solvent was removed under reduced pressure, and the residue was taken up in a chloroform/water mixture $(1: 1,100 \mathrm{~mL})$. After stirring for $1 \mathrm{~h}$ the products were extracted with chloroform. The organic layers were combined, washed with water, dried over $\mathrm{MgSO}_{4}$ and evaporated to dryness. The residue was treated with boiling ethanol followed by filtration of the starting material $\mathbf{1}$. The filtrate was evaporated, the residue was purified by column chromatography on silica gel (hexane/ chloroform 1:1) to afford cyanomethylated derivatives 2.

25-Cyanomethoxy-p-(tert-butyl)thiacalix[4]arene (2a). Colorless crystals (0.26 g, 36\%); mp $193-195{ }^{\circ} \mathrm{C} . \mathrm{R}_{f}=0.4\left(\mathrm{CHCl}_{3} / \mathrm{EtOH}=10: 1\right) .{ }^{1} \mathrm{H} \mathrm{NMR}\left(\mathrm{CDCl}_{3}\right): \delta 9.18(\mathrm{~s}, 1 \mathrm{H}, \mathrm{OH}), 8.58(\mathrm{~s}, 2 \mathrm{H}$, $\mathrm{OH}), 7.69(\mathrm{~d}, J=2.4 \mathrm{~Hz}, 2 \mathrm{H}, \mathrm{ArH}), 7.65$ (s, 2H, ArH), 7.64 (d, J=2.4 Hz, 2H, ArH), 7.59 (s, $2 \mathrm{H}, \mathrm{ArH}), 5.50\left(\mathrm{~s}, 2 \mathrm{H}, \mathrm{OCH}_{2}\right), 1.28\left[\mathrm{~s}, 18 \mathrm{H}, 2 \mathrm{C}\left(\mathrm{CH}_{3}\right)_{3}\right], 1.26\left[\mathrm{~s}, 9 \mathrm{H},\left[\mathrm{s}, 9 \mathrm{H}, \mathrm{C}\left(\mathrm{CH}_{3}\right)_{3}\right], 1.17[\mathrm{~s}\right.$, 9H, $\left.\mathrm{C}\left(\mathrm{CH}_{3}\right)_{3}\right] .{ }^{13} \mathrm{C} \mathrm{NMR}\left(\mathrm{CDCl}_{3}\right): \delta 155.96,155.73,155.13,150.11,144.05,143.87(\mathrm{ArC})$, 136.17, 135.92, 135.89, 135.67 (ArCH), 128.19, 120.34, $120.18(\mathrm{ArC}), 114.84\left(\mathrm{OCH}_{2} \mathrm{CN}\right), 59.90$ $\left(\mathrm{OCH}_{2} \mathrm{CN}\right), 34.38,34.05\left[\mathrm{C}\left(\mathrm{CH}_{3}\right)_{3}\right], 31.17,31.14,30.79\left[\mathrm{C}\left(\mathrm{CH}_{3}\right)_{3}\right]$. Anal. calcd. for $\mathrm{C}_{42} \mathrm{H}_{49} \mathrm{NO}_{4} \mathrm{~S}_{4}$ (760.12): C, 66.37 ; H, $6.50 \%$. Found: C, 66.06; H, $6.44 \%$.

25-Cyanomethoxy-p-H-thiacalix[4]arene (2b). White powder $(0.27 \mathrm{~g}, 51 \%)$; mp $229-230^{\circ} \mathrm{C}$; $\mathrm{R}_{f}=0.35\left(\mathrm{CHCl}_{3} / \mathrm{EtOH}=10: 1\right) .{ }^{1} \mathrm{H}$ NMR $\left(\mathrm{DMSO}-d_{6}\right): \delta 7.51-7.45(\mathrm{~m}, 4 \mathrm{H}, \mathrm{ArH}), 7.43(\mathrm{~d}, J=$ $8.0 \mathrm{~Hz}, 2 \mathrm{H}, \mathrm{ArH}), 7.22$ (d, $J=9.4 \mathrm{~Hz}, 2 \mathrm{H}, \mathrm{ArH}), 6.91$ (t, $J=9.4 \mathrm{~Hz}, 1 \mathrm{H}, \mathrm{ArH}), 6.76(\mathrm{t}, J=10.8$ $\mathrm{Hz}, 2 \mathrm{H}, \mathrm{ArH}), 7.71(\mathrm{~d}, J=8.0 \mathrm{~Hz}, 2 \mathrm{H}, \mathrm{ArH}), 5.34\left(\mathrm{~s}, 2 \mathrm{H}, \mathrm{OCH}_{2}\right) .{ }^{13} \mathrm{C} \mathrm{NMR}\left(\mathrm{DMSO}-d_{6}\right): \delta$ 158.01, 157.25, 156.36, (ArC), 136.73, 136.10, 135.69, 133.85 (ArCH), 130.37 (ArC), 126.01 $(\mathrm{ArCH}), 121.98,121.89(\mathrm{ArC}), 120.37,120.23(\mathrm{ArCH}), 116.65\left(\mathrm{OCH}_{2} \mathrm{CN}\right), 56.09\left(\mathrm{OCH}_{2} \mathrm{CN}\right)$. Anal. calcd. for $\mathrm{C}_{26} \mathrm{H}_{17} \mathrm{NO}_{4} \mathrm{~S}_{4}$ (535.69): C, 58.30; H, 3.20 Found: C, 57.66; H, 3.09.

25- $\mathbf{N - ( 1 - A d a m a n t y l ) c a r b a m o y l m e t h o x y - p - ( t e r t - b u t y l ) t h i a c a l i x [ 4 ] a r e n e ~ ( 3 a ) . ~ A ~ s o l u t i o n ~ o f ~ 2 a ~}$ (150 mg, $0.2 \mathrm{mmol})$, 1-adamantanol (60 mg, $0.4 \mathrm{mmol})$ in TFA/dichloroethane $(1: 1,2 \mathrm{~mL})$ was maintained at $60{ }^{\circ} \mathrm{C}$ for $8-20 \mathrm{~h}$. On completion of the reaction, the solvents were removed at reduced pressure. The residue was triturated with ethanol, the solid product was filtered off and purified by column chromatography on silica gel (hexane/chloroform/ethanol) yielding colorless crystals 3a (120 mg, 67\%); mp 284-286 ${ }^{\circ} \mathrm{C} ; \mathrm{R}_{f}=0.35\left(\mathrm{CHCl}_{3} / \mathrm{EtOH}=10: 1\right) .{ }^{1} \mathrm{H} \mathrm{NMR}\left(\mathrm{CDCl}_{3}\right)$ : $\delta 9.51(\mathrm{~s}, 1 \mathrm{H}, \mathrm{OH}), 9.10(\mathrm{~s}, 2 \mathrm{H}, \mathrm{OH}), 8.45(\mathrm{~s}, 1 \mathrm{H}, \mathrm{CONH}), 7.79(\mathrm{~d}, J=2.4 \mathrm{~Hz}, 2 \mathrm{H}, \mathrm{ArH}), 7.75$ (s, 2H, ArH), $7.71(\mathrm{~d} J=2.4 \mathrm{~Hz}, 2 \mathrm{H}, \mathrm{ArH}), 7.69$ (s, 2H, ArH), 4.69 (s, 2H, OCH $), 2.40(\mathrm{~m}, 6 \mathrm{H}$, $\left.\mathrm{AdCH}_{2}\right), 2.24$ (bs, 3H, $\left.\mathrm{AdCH}\right), 1.89-1.70\left(\mathrm{~m}, 6 \mathrm{H}, \mathrm{AdCH}_{2}\right), 1.33$ [s, 18H, C(CH $\left.)_{3}\right], 1.32$ [s, 9H, $\left.\mathrm{C}\left(\mathrm{CH}_{3}\right)_{3}\right], 1.26\left[\mathrm{~s}, 9 \mathrm{H}, \mathrm{C}\left(\mathrm{CH}_{3}\right)_{3}\right] .{ }^{13} \mathrm{C} \mathrm{NMR}\left(\mathrm{CDCl}_{3}\right): \delta 166.65(\mathrm{CONH}), 157.12,156.26,155.69$, 149.96, 144.42, 143.93 (ArC), 136.86, 136.27, 136.02, 135.94 (ArCH), 127.94, 120.59, 120.54, $119.52(\mathrm{ArC}), 77.11\left(\mathrm{OCH}_{2}\right), 52.43\left(\mathrm{AdC}_{1}\right), 41.32\left(\mathrm{AdC}_{2,8,9}\right), 36.35\left(\mathrm{AdC}_{4,6,10}\right), 34.39,34.15$, 
$34.02\left[\mathrm{C}\left(\mathrm{CH}_{3}\right)_{3}\right], 31.20,31.11,30.82\left[\mathrm{C}\left(\mathrm{CH}_{3}\right)_{3}\right], 29.48\left(\mathrm{AdC}_{3,5,7}\right)$. Anal. calcd. for $\mathrm{C}_{52} \mathrm{H}_{65} \mathrm{NO}_{5} \mathrm{~S}_{4}$ (912.36): C, 68.46; H, 7.18. Found: C, 68.23; H, 7.03.

\section{6,27,28-Tri(ethoxycarbonylmethoxy)-25- $N$-(1-adamantyl)carbamoylmethoxy-p-(tert-}

butyl)thiacalix [4]arene (4a). A mixture of 3a (90 mg, $0.1 \mathrm{mmol}), \mathrm{Na}_{2} \mathrm{CO}_{3}$ (640 mg, $6 \mathrm{mmol}$ ) and ethyl bromoacetate $(0.67 \mathrm{ml}, 6 \mathrm{mmol})$ in dry acetone $(10 \mathrm{~mL})$ was refluxed under argon for $40 \mathrm{~h}$. After cooling, the solid residue was removed by filtration and washed with dichloromethane. The organic solution was evaporated to dryness, the residue was washed with $0.2 \mathrm{~N} \mathrm{HCl}$ and water, dried over $\mathrm{P}_{2} \mathrm{O}_{5}$ and purified by column chromatography on silica gel (hexane/chloroform/ethanol) to give $4 \mathrm{a}(77 \mathrm{mg}, 66 \%)$ as a colorless crystals, $\mathrm{mp} 152-155{ }^{\circ} \mathrm{C}$. $\mathrm{R}_{f}$ $=0.35\left(\mathrm{CHCl}_{3} / \mathrm{EtOH} 10: 1\right) .{ }^{1} \mathrm{H} \mathrm{NMR}\left(\mathrm{CDCl}_{3}\right): \delta 8.05(\mathrm{~s}, 1 \mathrm{H}, \mathrm{CONH}), 7.37(\mathrm{~d}, J=2.6 \mathrm{~Hz}, 2 \mathrm{H}$, $\operatorname{ArH}), 7.34$ (s, 2H, ArH), 7.33 (d, 2H, J=2.6 Hz, 2H, ArH), 7.21 (s, 2H, ArH), 5.29 (d, J=6.3 $\left.\mathrm{Hz}, 2 \mathrm{H}, \mathrm{OCH}_{2} \mathrm{COO}\right), 5.09$ (d, $\left.J=6.3 \mathrm{~Hz}, 2 \mathrm{H}, \mathrm{OCH}_{2} \mathrm{COO}\right), 5.06$ (s, 2H, OCH $\mathrm{COO}_{2}, 4.87$ (s, 2H, $\mathrm{OCH}_{2} \mathrm{CONH}$ ), 4.23 (m, 6H, $\mathrm{OCH}_{2} \mathrm{CH}_{3}$ ), 2.19 (bs, 6H, $\left.\mathrm{AdCH}_{2}\right), 2.09$ (bs, 2H, AdCH), 1.77-1.66 $\left(\mathrm{m}, 6 \mathrm{H}, \mathrm{AdCH}_{2}\right), 1.31-1.25\left(\mathrm{~m}, 9 \mathrm{H}, \mathrm{OCH}_{2} \mathrm{CH}_{3}\right), 1.14$ [s, 9H, $\left.\mathrm{C}\left(\mathrm{CH}_{3}\right)_{3}\right], 1.10$ [s, 9H, $\left.\mathrm{C}\left(\mathrm{CH}_{3}\right)_{3}\right]$, $1.06\left[\mathrm{~s}, 9 \mathrm{H}, \mathrm{C}\left(\mathrm{CH}_{3}\right)_{3}\right] .{ }^{13} \mathrm{C} \mathrm{NMR}\left(\mathrm{CDCl}_{3}\right): \delta 169.21(\mathrm{COO}), 168.18(\mathrm{CONH}), 159.05,157.12$, 156.55, 146.39, 146.21 (ArC), 134.77, 134.48, 133.63, 133.25 (ArCH), 129.45, 128.57, 128.09, 127.52 (ArC), $75.53\left(\mathrm{OCH}_{2} \mathrm{CONH}\right), 70.26,70.03\left(\mathrm{OCH}_{2} \mathrm{COO}\right), 60.67,60.60\left(\mathrm{OCH}_{2} \mathrm{CH}_{3}\right), 52.06$ $\left(\mathrm{AdC} C_{1}\right), 41.28\left(\mathrm{AdC}_{2,8,9}\right), 36.25\left(\mathrm{AdC}_{4,6,8}\right), 34.05,33.95\left[\mathrm{C}\left(\mathrm{CH}_{3}\right)_{3}\right], 31.05,30.99,30.93$ $\left[\mathrm{C}\left(\mathrm{CH}_{3}\right)_{3}\right], 29.39\left(\mathrm{AdC}_{3,5,7}\right), 14.03\left(\mathrm{OCH}_{2} \mathrm{CH}_{3}\right)$. Anal. calcd. for $\mathrm{C}_{64} \mathrm{H}_{83} \mathrm{NO}_{11} \mathrm{~S}_{4}(1170.63)$ : C, 65.67; H, 7.15. Found: C, 65.08; H 6.98.

\section{Acknowledgements}

This work was supported by the Russian Foundation of Fundamental Researches (grant N 05-0332845)

\section{References}

1. (a) Morohashi, N.; Narumi, F.; Iki, N.; Hattori, T.; Miyano, S. Chem. Rev. 2006, 106, 5291. (b) Lhoták, P. Eur. J. Org. Chem. 2004, 1675. (c) Shokova, E.; Kovalev, V. Russ. J. Org. Chem. 2003, 39, 1.

2. Kumagai, H.; Hasegawa, M.; Miyanari, S.; Sugawa, Y.; Sato, Y.; Hori T.; Ueda, S.; Kaniyama, H.; Miyano, S. Tetrahedron Lett. 1997, 38, 3971.

3. Iki, N.; Kabuto, C.; Fukushima, T.; Kumagai, H.; Takeya, H.; Miyanari, S.; Miyashi, T.; Miyano, S. Tetrahedron 2000, 56, 1437.

4. Shokova, E.; Tafeenko, V.; Kovalev, V. Tetrahedron Lett. 2002, 43, 5153.

5. Lhoták, P.; Smejkal, T.; Stibor, I.; Havlichek, J.; Tkadlecova, M.; Petrickova, H. Tetrahedron Lett. 2003, 44, 8093. 
6. Matsumiya, H.; Terazono, Y.; Iki, N.; Miyano, S. J. Chem. Soc., Perkin Trans. 2 2002, 1166.

7. (a) Iki, N.; Narumi, F.; Fujimoto, T.; Morohashi, N.; Miyano, S. J. Chem. Soc., Perkin Trans. 2 1998, 2745. (b) Lhoták, P.; Himl, M.; Pakhomova, S.; Stibor, I. Tetrahedron Lett. 1998, 39, 8915. (c) Akdas, H.; Mislin, G.; Graf, E.; Hosseini, M. W.; De Cian, A.; Fisher, J. Tetrahedron Lett. 1999, 40, 2113. (d) Morohashi, N.; Iki, N.; Kabuto, C.; Miyano, S. Tetrahedron Lett. 2000, 41, 2933. (e) Akdas, H.; Jaunky, W.; Graf, E.; Hosseini, M. W.; Planeix, J.-M.; De Cian, A.; Fisher, J. Tetrahedron Lett. 2000, 41, 3601. (f) Lamartine, R.; Bavoux, C.; Vocanson, F.; Martin, A.; Senlis, G.; Perrin, M. Tetrahedron Lett. 2001, 42, 1021. (g) Akdas, H.; Bringel, L.; Bulach, V.; Graf, E.; Hosseini, M. W.; De Cian, A. Tetrahedron Lett. 2002, 43, 8975. (h) Lhoták, P.; Himl, M.; Stibor, I.; Petřičkova H. Tetrahedron Lett. 2002, 43, 9621. (i) Stoikov, I. I.; Omran, O. A.; Solovieva, S. E.; Latypov, S. K.; Enikeev, K. M.; Gubaidullin, A. T.; Antipin, I. S.; Konovalov, A. I. Tetrahedron 2003, 59, 1469.

8. (a) Lamare, V.; Dozol, J.-F.; Thuéry, P.; Nierlich, M.; Asfari, Z.; Vicens, J. J. Chem. Soc., Perkin Trans. 2 2001, 1920. (b) Grün, A.; Csokai, V.; Parlagh, G.; Bitter, I. Tetrahedron Lett. 2002, 43, 4153. (c) van Leewen, F.; Beijleveld, H.; Kooijman, H.; Spek, A.; Verboom, W.; Reinhoudt, D. Tetrahedron Lett. 2002, 43, 9675.

9. (a) Iki, N.; Morochashi, N.; Narumi, F.; Fujimoto, T.; Suzuki, T.; Miyano, S. Tetrahedron Lett. 1999, 40, 7337. (b) Lhoták, P.; Kaplánek, M.; Stibor, I.; Lang, J.; Dvořáková, H.; Hrabal, R.; Sýkora, J. Tetrahedron Lett. 2000, 41, 9339. (c) Lhoták, P.; Dudic, M.; Stibor, I.; Petrickova, H.; Sýkora, J.; Hodacova, J. Chem. Comm. 2001, 731. (d); Csokai, V.; Grün, A.; Parlagh, G.; Bitter, I. Tetrahedron Lett. 2002, 43, 7627.

10. (a) Narita, M.; Higuchi, Y.; Hamada, F.; Kumagai, H. Tetrahedron Lett. 1998, 39, 8687. (b) Rao, P.; Hosseini, M. W.; De Cian, A.; Fisher, J. Chem. Commun. 1999, 2169. (c) Akdas, H.; Graf, E.; Hosseini, M. W.; Rao, P.; De Cian, A. J. Supramol. Chem. 2002, 2, 21.

11. Bitter, I.; Csokai, V. Tetrahedron Lett. 2003, 44, 2261.

12. Narumi, F.; Morohashi, N.; Matsumura, N.; Iki, N.; Kameyama, H.; Miyano, S. Tetrahedron Lett. 2002, 621.

13. Collins, E. M.; McKervey, M. A.; Madigan, E.; Moran, M. B.; Owens, M.; Ferguson, G.; Harris, S. J. J. Chem. Soc., Perkin Trans. 1 1991, 3137.

14. Nam, K. C.; Kang, S. O.; Ki, Y. J. Supramol. Chem. 2002, 14, 503.

15. Bhalla, V.; Kumar, M.; Kabuto, C.; Hattori, T.; Miyano, S. Chem. Lett. 2004, 33, 184.

16. Da Silva, E.; Coleman, A. W. Tetrahedron 2003, 59, 7357.

17. Santoyo-Gonzalez, F.; Torres-Pinedo, A.; Sanchez-Ortega, A. J. Org. Chem. 2000, 65, 4409.

18. Kovalev, V. V., Khomich, A. N.; Shokova, E. A., Luzikov, Yi, N. New. J. Chem. 1996, 20, 483. 